\title{
膀胱尿管逆流の臨床経過
}

東京大学医学部泌尿器科教室 (主任：高安久雄教授)

小川秋実

\section{CLINICAL COURSE OF VESICOURETERAL REFLUX}

\author{
Akimi Ogawa \\ From the Department of Urology, Faculty of Medicine, The University of Tokyo \\ (Director: Prof. H. Takayasu)
}

The clinical course of 44 patients with vesicoureteral reflux was analysed. The patients were folowed for at least one year and on the average for 3 years and 10 months after diagnosis. Of these 44 patients, 29 had primary reflux and 15 had reflux secondary to neurogenic bladder, urinary tract tuberculosis, radical hysterectomy for cervical carcinoma, ureteral re-implantation or cystoplasty. The age and sex distribution are given in Table 1. The chief complaint, X-ray findings and urinalysis at diagnosis are presented in Table 2.

Nineteen patients who had recurrent attacks of acute pyelonephritis were treated by sulfonamides (sulfamethizole 2 to $3 \mathrm{gm}$ per day) for more than 6 months. Twelve patients with primary reflux responded well to the medication and experienced no fever and no urinary infection during the follow-up period (Table 3). All patients with successful long-term sulfa-therapy except one had normal upper urinary tract on urography.

Anti-reflux operations were performed in 15 patients. Though the reflux was stopped in all cases at the time of discharge, it recurred in 8 out of 10 patients who underwent cystographic check-up more than 6 months after the operation (Table 4). However, successful eradication of pyelonephritic attack and urinary infection was obtained in 7 out of 10 patients with primary reflux (Table 5).

Despite medication, 12 patients had presistent pyuria, 10 of which showed pyelonephritic or hydronephrotic changes on X-ray examination (Table 6). In 4 patients with persistent pyuria the reflux was completely asymptomatic without demonstrable progressive changes on pyelograms.

Progressive damage to the refluxed kidney during the follow-up period of an average of 5 years and 7 months was noted in one patient with primary reflux and 5 with secondary reflux (Table 7). Renal deterioration of these patients was due to hydronephrotic change.

The results of this study would suggest that presence of non-obstructive reflux, even with urinary infection, is not always noxious to the kidney and primary reflux does not damage the kidney in the majority of cases though it may cause recurrent acute pyelonephritis. It seems likely that the pyelonephritic contracted kidney due to reflux rarely develops.

Long-term sulfonamides medication will be the treatment of choice for the patients with primary reflux suffering from pyelonephritic attacks when the upper urinary tract is nearly intact. If the medication fails or progressive renal damage is demonstrated, surgical measures will be indicated. Patients with asymptomatic reflux and persistent urinary infection must be kept under close surveillance, since progressive damage to the kidney may occur occasionally.

\author{
緒言 \\ 膀胱尿管逆流に関する知見は最近 10 数年間に飛躍的進 \\ 歩をとげている．正常人には逆流はなく，尿路結核，前 \\ 立腺疾患, 膀脱の手術後, 神経因性膀胀等に逆流が合併
}

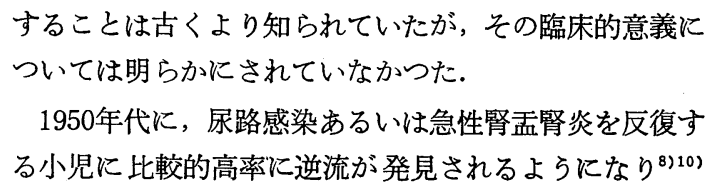

することは古くより知られていたが，その臨床的意義に ついては明らかにされていなかつた。

1950年代に，尿路感染あるいは急性腎盂腎炎を反復す る小児に比較的高率に逆流が発見されるようになり ${ }^{8) 10}$ 
12), また Hutch (1952) ${ }^{15)}$ が神経因性膀胱患者の逆流に 対し初めて逆流防止術に成功したため, にわかに関心が 向けられるようになつた。ついで， $\mathrm{X}$ 線的に慢性腎孟腎 炎の変化のみられる腎にも逆流の多いことが報告された が $^{13)(4)}$ ，それ以前に，慢性腎不全の原因には慢性腎盐腎 炎が少くないとの指摘があつたため ${ }^{31)}$, 逆流と慢性腎需 腎炎との因果関係が論じられるようになつた。

下部尿路閉塞, 神経因性膀胱, 尿管の奇形等の器質的 次患のいずれもない小児にみられる逆流は，おそらく膀 胱䅡部閉塞があるものとして一時期は膀胱䅡部形成術が 行われていた. しかし1965年 Tanagho \& $\mathrm{Hutch}^{30)}$ がこ れらの症例の逆流は先天的に三角部等層が脆弱であるた めに生ずるものと説明し，これを先天性原発性逆流と名 つけけたしいもこのよらな症例では患側の三角部は拡大 し，尿管口は開放しておうり，しばしば巨大膀朕を伴らこ とが明らかになつた ${ }^{11220) 221}$

正常人の逆流防止機構は, Tanagho \& Pugh (1963) 29 に上り,下部㽷管より三角部へ放散する筋線維が収縮し て壁内尿管の延長と尿管口の閉鎖を起すことによるとさ れている. 従来考えられていた膀胧粘膜下尿管の受動的 并作用は，逆流防止に関与するが主役をなすとは考兄ら れていない。

逆流を原因別に分類すると次のようになる。

1）先天性逆流：i）原発性（三角部脆弱），ii）尿管 奇形 (重複尿管, 異所開口, 尿管瘤) および尿管裂孔先 天性開大.

2）続発性逆流：ｉ）下部尿路閉塞，ii）神経因性膀 胀，3）膀洸の炎症，4）医原性（尿管膀胱新吻合等）. 逆流の治療については, 下部尿路閉塞があればこれを 是正すべきことに異論はなく, 膀羘の炎症があればその 治療を行らことは論をまたないが，その他の逆流につい ては必ずしも意見の一致をみていない，小児の原発性逆 流は, その多数が保存的療法で, あるいは自然に, 逆流 の消失することが報告され(3)(21)28)33)，扣とらく三角部
筋層の成熟によるものと理解されている．このように逆 流の消失するものは別として, 逆流が継続して存在する ときは積極的に逆流防止術を行らべきか，あるいはでき るだけ保存的に処置すべきかについては見解の統一はみ られていない，それは逆流が必ず進行性腎障害を起する のか否かといらことに関係する.

この報告では, 最近 5 年間に経験した这流の症例のう ち， 1 年以上経過を追跡した 44 症例について, 病像の経 過, 治療法の効果を検討し, 逆流の治療方針について若 干の見解を述べる.

\section{対象症例}

昭和 43 年 1 月より昭和 47 年 12 月までの 5 年間に東京大 学医学部附属病院泌尿器科を受診した膀腅尿管这流の症 例のらち， 1 年以上経過を追跡した 44 症例を対象とし た. うち14例は昭和 43 年 1 月以前より程過を観察してい た. 追跡期間は最長 9 年, 平均 3 年10カ月であつた.

逆流の原因が不明のものを原発性逆流, 逆流を発生し らる疾患の存在するときは続発性逆流として分類した. ただし急性単純性膀胱炎を契機として発症し，他に異常 を認めないものは原発性逆流とした。

続発性逆流は, 1 年以上無処置または保存的療法のみ で追跡した症例, あるいは原因疾患の治療に拘らず逆流 の継続した症例, あるいは逆流防止術を施行した症例で あり, その原因疾患は, 神経因性膀胱 6 例, 尿路結核 2 例, 子宮癌根治手術後 2 例, 膀脱尿管新吻合術後 3 例, 膀胼形成術後 2 例であつた.

症例の性別, 初診時年令別の内訳は表 1 亿, 初診時の 所見は表 2 に示す。

初診時の主訴は, 原発性逆流では急性腎昷腎炎による 発熱の反復が大多数を占め, 残りは血尿 (3 例),蛋白尿 （1 例)，1 回のみの発熱（1 例）であつた. 続発性逆流 では発熱の反復を主訴とするものは4 例のみで, 残りは 原疾患による症状が主訴であつた。

逆流は $15 \mathrm{~cm}$ 水柱圧, $60 \mathrm{~cm}$ 水柱圧および排尿時の膀胱造

装 1 対象症例の性および年令分布

\begin{tabular}{c|l|c|c|c|c|c|c|c|c}
\hline \multicolumn{2}{c|}{ Age } & $\sim 10$ & $\sim 20$ & $\sim 30$ & $\sim 40$ & $\sim 50$ & $\sim 60$ & $\sim 70$ & total \\
\hline \multirow{2}{*}{ Primary reflux } & male & 5 & & & 1 & & & 1 & 7 \\
\cline { 2 - 9 } & female & 2 & 3 & 12 & 4 & 1 & & & 22 \\
\hline \multirow{2}{*}{ Secondary reflux } & male & 1 & 2 & 1 & 2 & 1 & & & 7 \\
\cline { 2 - 9 } & female & 1 & 1 & 1 & 2 & 2 & & 1 & $\frac{7}{8}$ \\
\hline
\end{tabular}


表 2 初診時所見

\begin{tabular}{|c|c|c|c|}
\hline & & $\begin{array}{l}\text { Primary } \\
\text { reflux }\end{array}$ & $\begin{array}{c}\text { Secondary } \\
\text { reflux }\end{array}$ \\
\hline \multirow{2}{*}{$\begin{array}{l}\text { Chief } \\
\text { complaint }\end{array}$} & recurrrent fever & 24 & 4 \\
\hline & others & 5 & 11 \\
\hline \multirow{3}{*}{ Side } & unilateral reflux & 19 & 5 \\
\hline & bilateral reflux & 9 & 5 \\
\hline & $\begin{array}{l}\text { reflux to solitary } \\
\text { kidney }\end{array}$ & 1 & 5 \\
\hline \multirow{2}{*}{ Pyelogram } & normal & 18 & 3 \\
\hline & abnormal & 11 & 12 \\
\hline \multirow{3}{*}{ Urinalysis } & no urinary infection & 2 & 2 \\
\hline & pyuria & 20 & 13 \\
\hline & $\begin{array}{l}\text { pyuria only during } \\
\text { febrile period }\end{array}$ & 7 & 0 \\
\hline
\end{tabular}

影で診断し，1回でも逆流像の認められたものを患側と した，急性腎需腎を反復する症例のうち，初診時には 逆流が認められず，発熱発作の前後にのみ逆流が発見さ れたものが 3 例あつた。

初訅時の排泄性腎皿撮影（以下 IVP と略す）で，逆 流側の腎賈尿管に腎盂腎炎性変化 ${ }^{14}$ あるいは水腎水尿管 を認めたものを異常とした。

尿所見では膿尿と細菌尿の両者またはいずれかのある ものを尿感染ありとした．初診時の尿検査では感染を認 めなかつたが，逆行的検査後に尿感染の持続したものは 原発性逆流に 2 例, 続発性逆流に 1 例あつたが，これは 初診時より康感染があるものとした.

\section{結 果}

I 、急性腎血腎炎を反復する逆流に対する長期サルフ >剂投与の効果

急性腎血腎炎の反復のある19例（逆流防止術が不成功 であつた 2 例を含む）に対し 6 カ月以上のサルファ斉投 与 (Sulfamethizole 1 日 $2 \sim 3 \mathrm{~g}$ ) を行つたが（表3）， 原発性逆流の12例では発熱も尿所見も完全に消失した. この有効例では 1 例を除いて腎孟像に異常は認められな かつた。他方, 無効の 7 例中 5 例に腎血像の異常があつ た．有効例で逆流が消失したか否かについては，一部の 症例を除いて検査を施行しなかつたので，判定できなか つた。サルファ斉投与は症状消裉後 6 力月以上を経て中 止または減量して継続投与した。無効の5ち 2 例に対 し逆流防止術を施行したが，術後は発熱も尿所見も消失 した.

II . 逆流防止手術の効果

逆流防止術を受けた症例は15例であつた．他院医師に
表 3 急性腎孟腎炎を反復する逆流に対する 長期サルファ剂投与の竣果

\begin{tabular}{c|c|c}
\hline $\begin{array}{c}\text { Result of long-term } \\
\text { sulfonamides medication }\end{array}$ & $\begin{array}{c}\text { Primary } \\
\text { reflux }\end{array}$ & $\begin{array}{c}\text { Secondary } \\
\text { reflux }\end{array}$ \\
\hline $\begin{array}{l}\text { Fever and urinary infection } \\
\text { ceased }\end{array}$ & $12(1)$ & 0 \\
\hline $\begin{array}{l}\text { Frequency of fever attack } \\
\text { decreased }\end{array}$ & $2(1)$ & 0 \\
\hline Unchanged & $3(2)$ & $2(2)$ \\
\hline Total & $17(5)$ & $2(2)$ \\
\hline
\end{tabular}

Number in parenthesis denotes the cases with pyelographic changes.

洨 4 逆流防止術の成績（術後 6 力月以降）

\begin{tabular}{c|c|c}
\hline $\begin{array}{c}\text { Late result of } \\
\text { anti-reflux operation }\end{array}$ & $\begin{array}{c}\text { Primary } \\
\text { reflux }\end{array}$ & $\begin{array}{c}\text { Secondary } \\
\text { reflux }\end{array}$ \\
\hline Reflux stopped & 1 & 1 \\
\hline Reflux recurred & 8 & 1 \\
\hline Not examined & 4 & 0 \\
\hline Total & 13 & 2 \\
\hline
\end{tabular}

表 5 急性腎搵腎の反復に対する逆流 防止術の効果

\begin{tabular}{|c|c|c|c|}
\hline \multirow{2}{*}{$\begin{array}{c}\text { Effect of } \\
\text { anti-reflux } \\
\text { operation on } \\
\text { recurrent acute } \\
\text { pyelonephritis }\end{array}$} & \multicolumn{3}{|c|}{$\begin{array}{c}\text { Patients with primary reflux } \\
\text { (10 cases) }\end{array}$} \\
\hline & $\begin{array}{l}\text { successful } \\
\text { operation }\end{array}$ & $\begin{array}{l}\text { cystography } \\
\text { not done } \\
\text { later }\end{array}$ & $\begin{array}{l}\text { unsuccessful } \\
\text { operation }\end{array}$ \\
\hline $\begin{array}{l}\text { Fever ceased } \\
\text { immediately }\end{array}$ & 1 & 3 & 1 \\
\hline $\begin{array}{l}\text { Fever ceased } \\
\text { gradually }\end{array}$ & & 1 & 1 \\
\hline Unchanged & & & 3 \\
\hline
\end{tabular}

より手術を受けた 3 例を除いた 12例（Grégoir 法 9 例， Paquin 法 3 例)では, 退院時の膀胱造影では逆流は消失 していた。しかし術後 6 カ月以上を経て再検査を行つた 11例（他院医師による手術例を含む）のらち9例に逆流 の再発がみられた(表 4). 再発のなかつた 2 例は Paquin 法により逆流防止術を行つた症例であつた.

急珄腎需腎炎を反復した原発性逆流のうち逆流防止術 を受けたものは10例であつた（表 5 ）.その5ち 7 例では 術後直ちに，あるいは徐々に発熱も尿所見も消失した. しかしこの 7 例中少くとも 2 例では逆流が再発してい た.

III. 持続的膿尿を伴う逆流の経過 治療に抵抗して持続的に膿尿を呈した逆流は12例であ 
表 6 持続的膿尿を伴う逆流の経過

\begin{tabular}{l|c|c|c}
\hline $\begin{array}{c}\text { Reflux with } \\
\text { persistent pyuria } \\
\text { (12 cases) }\end{array}$ & $\begin{array}{c}\text { Primary } \\
\text { reflux }\end{array}$ & $\begin{array}{c}\text { Secondary } \\
\text { reflux }\end{array}$ & Total \\
\hline Asymptomatic & $2(2)$ & $2(2)$ & $4(4)$ \\
\hline $\begin{array}{l}\text { Fever one or } 2 \\
\text { times a year }\end{array}$ & $1(1)$ & $2(2)$ & $3(3)$ \\
\hline $\begin{array}{l}\text { Recurrent fever and } \\
\text { progressive renal } \\
\text { damage }\end{array}$ & $\begin{array}{l}\text { Aama } \\
\begin{array}{l}\text { Progressive renal } \\
\text { damage without } \\
\text { fever attack }\end{array}\end{array}$ & $3(2)$ & $3(2)$ \\
\hline
\end{tabular}

Number in parenthesis denotes the cases with pyelographic changes

* : Urethral catheter is placed.

つた（表 6 ）.原発性逆流の 3 例は逆流防止術を行つたが 逆流の再発した症例であつた。12例のうち10例では初診 待: IVP で迹流側に異常が認められた，12例中5例では 急性腎盐腎炎の反復が続き，6例では逆流側の腎昷像の 覀化あるいは腎機能低下が経過観察中に進行性に認めら れた。他方, 全く無症候で進行性の腎障害もなく, 膿尿 のみを呈するものは 4 例であつた.

IV. 逆流による腎障害

手術により逆流の消失した症例を除いて，4 年以上経 過を追跡した症例は21例（平均追跡期間：原発性 5 年, 続発性 6 年 3 カ月）であつたが（表 7 ）,このらちX線的 あるいは腎機能検査（両側逆流または単腎の逆流のと

表 74 年以上追跡した逆流の経過

\begin{tabular}{l|c|c|c}
\multicolumn{1}{c|}{$\begin{array}{c}\text { Reflux followed more } \\
\text { than 4 years (21 cases) }\end{array}$} & \multicolumn{2}{c}{$\begin{array}{c}\text { Primary } \\
\text { reflux } \\
\text { (11 cases) }\end{array}$} & $\begin{array}{c}\text { Secondary } \\
\text { reflux } \\
(10 \text { cases })\end{array}$ \\
\hline Progressive renal damage & 1 & 5 \\
\hline $\begin{array}{l}\text { Asymptomatic } \\
\text { without } \\
\text { progressive renal } \\
\text { damage }\end{array}$ & $\begin{array}{l}\text { without } \\
\text { urinary } \\
\text { infection }\end{array}$ & 3 & 3 \\
\hline
\end{tabular}

き）で逆流腎に進行性の腎障害があつたと判断されるも のは6 例であつた. 他に一側の原発性逆流で総腎機能の 低下したものが 2 例あつたが，いずれも逆流のない対側 腎があり, 高度の蛋白尿を呈していたため, 逆流以外に よる腎障害と考えて除外した。

筒障害の進行がみられたのは, 原発性逆流では 1 例の みであつたが，続発性逆流では 5 例に認められ，その原 因疾患は神経因性膀胱（3 例), 腎結核治癒後のさんご状 結石形成（1 例),膀脂形成術後（1 例）であつた。腎障
害の進行した症例は，いずれも持続的膿尿を呈し，形態 的には水腎性変化を示した。経過観察中に腎監炎性萎 縮腎へ進行したものはなからた。

$\mathrm{V}$. 無症候性逆流

4 年以上経過を追跡した21例中, 急性腎需腎炎も逆流 骶の進行性腎障害も示さず, 逆流に関しては無症候であ るものは 8 例であつた（表 7 ）.この 8 例中 6 例では初診 時 IVP に巽常が認められ，4例では持続的膿尿を示し た。

\section{VI. 全政例の最終結果を表 8 に示す}

無処置あるいは保存的か外科的処置により，発熱も尿 所見もなく，進行性の腎障害もみられず，臨床的には定 期的観察（一部はサルファ剂服用中）のみの症例は，原

\section{表 8 企症例の最終結果}

\begin{tabular}{|c|c|c|c|c|c|}
\hline \multirow{2}{*}{\multicolumn{2}{|c|}{ Final measures }} & \multicolumn{4}{|c|}{ Final results } \\
\hline & & \multirow{2}{*}{$\mid \begin{array}{c}\begin{array}{c}\text { no fever, } \\
\text { no urinary } \\
\text { infection }\end{array} \\
12\end{array}$} & \multirow{2}{*}{$\begin{array}{c}\text { pyuria } \\
\text { without } \\
\text { fever }\end{array}$} & \multirow{2}{*}{$\begin{array}{c}\begin{array}{c}\text { recurrent } \\
\text { fever } \\
\text { attacks }\end{array} \\
2\end{array}$} & \multirow{2}{*}{$\begin{array}{l}\text { progressi- } \\
\text { ve renal } \\
\text { damage }\end{array}$} \\
\hline \multirow{3}{*}{ 胥号 } & $\begin{array}{l}\text { Long-term } \\
\text { sulfa-drug } \\
\text { medication } \\
\end{array}$ & & & & \\
\hline & $\begin{array}{l}\text { Anti-reflux } \\
\text { operation }\end{array}$ & 8 & 2 & 1 & \\
\hline & None & 3 & & & \\
\hline \multirow{3}{*}{ 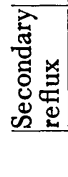 } & $\begin{array}{l}\text { Anti-reflux } \\
\text { operation }\end{array}$ & 1 & & & 1 \\
\hline & $\begin{array}{l}\text { None or } \\
\text { symptomatic }\end{array}$ & 5 & 2 & 2 & 4 \\
\hline & Total & 29 & 4 & 5 & 6 \\
\hline
\end{tabular}

発性逆流では23例（79\%），続発性逆流では6 例（40\%） であつた，逆流の消失の有無については一部の症例以外 は検査を行わなかつたので判定できなからた。

\section{考 按}

尿路閉塞性疾患がなくて急性腎盂腎炎を反復する症例 には高頻度に逆流が認められるが，このような症例に逆 流防止術を行うと急性腎盂腎炎の発作が消失したといら 報告は多く1)4233)32)，逆流が 急性腎盂腎炎の原因となり らることは，むはや否定できないことである.|

このような原発性逆流による急性腎盂腎炎の治療は， まず保存的療法を試みてみるといら見解が多(419933). 自験例では長期サルファ剂投与により17例中12例に急性 腎孟腎炎発作の消失，尿所見の正常化がみられている。 有効例では 1 例を除いて腎孟像に異常を認めなかつたこ と, 逆に無効 5 例中 3 例の腎孟像に変化があつたことか 
ら，逆流による急性腎盂腎炎発作は腎盂像が正常であれ ば保存的療法によく反応するといらことができる。

サルファ剤長期投与により, 逆流が消失したか否かは 自験例については明らかにできなかつたが，検查時に逆 流が消失していても間歇的逆流の可能性は残るため，正 確な消失率を求めることは困難であるう，小児では上部 尿路が正常であれば保存的療法により逆流の30 60\%が 消失することが 報告されている(3)421)28)33)，その理由の 一部には三角部の成熟があると考光られているが，他方 では三角部筋層の欠陥が軽度であれば，膀胱の炎症ある いはその他の刺激が加つたときに三角部不全が顕著にな り急性腎監腎を発症するが，同時に保存的療法によく 反応するとも考觉られる.間歇的逆流は三角部の欠陥が 特に軽度なためであろう．女性に逆流による急性腎孟腎 炎が多いのも女性に膀胱炎の多いことより説明できる。

逆流防止術の適応については最も議論のあるところで ある.手術療法の適応は殆んどないという意見から ${ }^{26) 28)}$ ， 感染のない逆流でる 手術を考慮すべきであるという意 見 ${ }^{17}$ まであるが，大勢は保存的療法で感染のとれない逆 流は手術療法を行うべきと考えている. 逆流防止の術式 としてはLeadbetter \& Politano 法, Paquin 法, Grégoir 法等が行われ, 逆流の消失については $90 \%$ 以上の成功率 が報告されている(1)416)23)32). しかし逆流が消失しても 尿感染の続く症例が10〜30\%に認められている.

自験例の逆流防止術の成績は, 退院時には逆流は消失 していたが, 術後 6 カ月以上を経て検査してみると高率 に逆流の再発がみられている.これには逆流防止術の技 術的問題も関係すると思われるので今後の検討を要しよ 万. 急性腎孟腎炎発作のあつた逆流のらち防止術を施行 した10例中 7 例に発熱も尿所見も改善がみられている. そのうち少くとも2 例では逆流の再発があるにも拘らず 症状が改善しているのは, 逆流があつてもその程度が軽 くなつたためと想像される。

治療に抵抗して持続的に膿尿を示した逆流は, 自験例 では腎盂像に異常のあるすのが汪とんどであり, うち半 数には腎障害の進行がみられている. 他方, 膿尿を伴う 逆流でも必ずしも発熱を反復するとは限らず，また進行 性の腎障害のみられない症例があることは注目すべきで ある.

逆流が長い間継続すれば慢性腎盘腎炎により腎が荒廃 し，両側性ならば腎不全に至ると一般に信じられている が、この説明にはかなりの疑問がある. 逆流は，たと光 感染がなくても, 進行性に腎障害を起すとする説の根拠
は，X線的に慢性腎盃腎炎性变化のみられる腎には逆流 が多いという事実に基いている(1314)17)，すなわち逆流の ために慢性腎孟腎炎性変化を生じたと解釈している。し かし，感染のない逆流で経過観察中に新しく腎孟腎炎性 変化が出現したといら報告はごく僅かである ${ }^{25)}$. 一方, 医原性の逆流が 長期間継続しても感染がなければ腎㙉 像も腎機能も殆んど変化がみられないという報告があ $3^{9224}$. 原発性逆流でも，Williams $(1971)^{33)}$ は，17年 間追跡して全く無症候で感染も腎盂像の变化のなかつた 1 例を経験している.

感染を伴う逆流では腎障害が進行するといらのは多数 意見であり，その症例も多数報告されているが，感染の ある逆流でも腎障害の 進行が みられないことがある.

Küss et al. $(1970)^{18)}$ は, 感染を伴う医原性逆流を10年 以上追跡して, 腎孟像, 血液生化学所見に变化はみら れなかつたと述べている. 自験例では 4 年から 9 年の 経過観察で, その間に進行性の腎障害が認められたの は, 原発性逆流では11例中 1 例のみであり, 続発性逆流 では10例中 5 例である. 続発性逆流の 5 例のうち 3 例は 神経因性膀脂, 1 例は単腎のさんご状結石, 1 例は膀胱 形成術後の症例であるため, 必ずしも逆流が腎機能悪化 の主因とはいい難い. しか子腎障害の進行した 6 例は， いずれる水腎性変化が進行したものであり, 腎盃腎炎性 萎縮腎へ移行したものはない.

以上のことより，逆流が継続しても必ずしも腎障害を 起するのではなく, 腎障害がみられるのは感染を伴ら逆 流で特に続発性逆流に多く, 原発性逆流では比較的少い と推論される。しかも逆流により腎典腎炎性萎縮腎へ 移行するものは，ごく稀ではないかと思われる，すなわ ち，逆流には急性腎孟腎炎の原因になつたり，腎障害を 起こしたりする有害な逆流と, 全く無症候性で, 腎障害 を起こすことのない無害な逆流があるといえる，その相 違は感染に対する腎の感受性の差によるものであろう。

Ericsson \& Ivemark (1958) $)^{7)}$ は, 尿路感染のため摘 出した腎の組織学的検討より, 腎組織中に高頻度に異形 成 (dysplasia) を認め, その部分に感染所見が限局して いることを見出している，逆流腎に組織学的に異形成を 認めたといら報告は若干あるが(2)27)，特に Boccon-Gibod et al. $(1972)^{5)}$ は, 原発性逆流による腎酉腎炎性萎縮腎 として腎摘された 12 コの腎の組織学的検査で, 純粋の慢 性腎孟腎炎を認めたのは 1 腎のみであり, 残りの11腎は 先天的に小さい腎で， 6 腎に異形成，5腎に部分的腎形 成不全があり, 炎症（間質性腎炎）の合併はこの11腎の 
らち5腎のみに認めている. しかも慢性腎孟腎炎と臨床 的に判断された変化は, 異形成とか形成不全とかの先天 的変化であり，腎孟腎炎性萎縮腎は極めて稀なものであ るとしている.

原発性逆流が三角部筋層の先天的異常とすれば，その 腎にも先天的異常が併発している可能性は充分に考只ら れる. Beck $(1971)^{21}$ は, 動物実験で妊娠前半期の胎児 に尿管閉塞を起こすと，その腎は水腎性萎縮腎となり， 組織学的に異形成に似た所見のみられることを報告して いるが，この結果から胎生期の膀腃尿管逆流により腎に 異形成を生ずるという可能性もある，乙かし，原因は不 明であるが，上部尿路の一側なり両側なりに系統的に先 天的異常を多発したと考觉てる不自然ではない。

腎が先天的異常のために感染への感受性が高く，そこ へ逆流を生ずれば急性炎症を頻発するであるうし，三角 部の異常のみで腎が正常ならば無症候性逆流であろう. 原発性逆流にしばしば合併する水尿管, 巨大膀胀も, 逆 流の結果ではなく, 尿管や膀腃の先天的異常と理解しう る. 腎孟像にはいわゆる腎孟腎炎性変化が顕著にみられ るが，全く無菌で感染の既往もなく，乙かも逆流の証明 されない症例に遭遇したときには, 従来は説明に困惑し たが，このような症例の腎孟像の変化は炎症に続発した あのではなく, 先天的変化であるとするならば首肯しう る. 医原性の逆流では腎障害も急性腎盂腎炎の反復もほ とんどみられないこと, 原発性逆流では手術で逆流が消 失しても感染の続く症例が10～30\%あること等は，この 説明の妥当性を示している.

尿路閉塞による腎感染が, 閉塞解除後に腎㙉腎杯の変 形と腎実質の萎縮といら慢性腎孟腎炎の典型的変化を示 すことは明白な事実である. しかし，X線的にこのよう な变化をみたとさに，すべて慢性腎盂腎炎によると考え るのは論理の飛躍である. 腎異形成等の先天的異常によ る変化と真の慢性腎㙉腎炎による变化を, どのように臨 床的に鑑別するかは今後の問題であろう。また， $\mathbf{X}$ 線的 には全く正常な腎をもつ原発性逆流で急性腎盂腎炎を反 復するとき，その腎に実際に先天的異常が存在するかど らかは今後解明を要しょう.

以上の検討から，非閉塞性逆流の治療方針は次のよう にするのが適切と思われる。

無症候で尿感染も進行性腎障害もないときは経過観察 のみでよい，急性腎㙉腎炎を反復する原発性逆流には先 ずサルファ剂長期投与を行ら．保存的療法に抵抗して発 熱が反復するときと，進行性腎障害のあるときは外科的
療法（逆流防止術, 腎摘除術または尿路变向）の適応で ある.膿尿または細菌尿を呈するが無症候のときは, 直 ちには手術の適応ではないが, 腎障害の進行することが あるので䈌重な観察を要する。

\section{結 語}

膀胱尿管逆流で 1 年以上 (平均 3 年10カ月) 経過観察 した44症例（原発性逆流29例, 続発性逆流15例）を検討 して次の結果がえられた.

1）急性腎孟腎炎を反復する逆流19例（原発性17例） に対し 6 カ月以上のサルファ剂投与を行つたところ，原 発性逆流の12例では発熱す尿所見も消失した. 有効例で は 1 例を除いて腎盂像は正常であつた.

2）逆流防止術を施行した15例（原発性13例）のう ち, 術後 6 カ月以降に逆流の検査をした10例中 8 例に逆 流の再発があつた. 急性腎㙉腎炎の反復する10例に逆流 防止術を行つたところ， 7 例では発熱る尿所見も消失し た.

3）難治性膿尿を伴ら逆流12例（原発性 3 例）のらち 10例では初診時よりX線的に腎監焱性变化あるいは水 腎性変化がみとめられた．12例中 5 例に発熱の反復, 6 例に進行性腎障害がみられたが，4 例は無症候性であつ た.

4） 4 年以上 (平均 5 年 7 カ月) 経過を追跡した 21 例 （原発性11例）のらち, 逆流による進行性腎障害を示し たものは, 原発性逆流では 1 例, 続発性逆流では 5 例で あり,いずれも持続性膿尿と水腎性変化を示した.

5） 4 年以上経過を追跡した21例のうち, 無症候性 で, 進行性腎障害すみられない逆流は8 例であつた.

有害な逆流と無害な逆流のあることを論し，逆流の治 療方針についての見解を述べた.

御指導御校閲を戴いた高安久雄教授に深謝いたしま す.

（本稿の要旨は第61回日本泌尿器科学会総会に於て発 表した。）

\section{文献}

1) Amar, A.D. \& Singer, B.: J. Urol. 109, 999, 1973.

2) Beck, A.D.: J. Urol. 105, 784, 1971.

3) Blight, Jr., E.M. \& O'Shaunessy, E.J.: J. Urol. 102, 44, 1969.

4) Brannan, M.G., Ochsner, D.R., Rosenkrantz, C.G., Whitehead, J.R. \& Goodier, E.H.: J. Urol. 109, 46, 1973.

5) Boccon-Gibod, L., Galian, P. \& Mme Boccon- 
Gibod, L.: Presse méd. 1, 507, 1972.

6) Cussen, L.J.: J. Urol. 106, 939, 1971.

7) Ericsson, N.O. \& Ivemark, B.I.: Acta chir. scandinav. 115, 58, 1958.

8) Forsythe, W.I. \& Whelan, R.F.: Brit. J. Urol. 30, 189, 1958.

9) Fritjofsson, A. \& Sundin, T.: Brit. J. Urol. 38, 445, 1966.

10) Garrett, R.A. \& Switzer, R.W.: J.A.M.A. 195, 636, 1966.

11) Grégoir, W.: 15e Congrès de la Société Internationale d'Urologie (Tokyo) 1970, Tome I, p. 143, G. et R. Joly (Paris).

12) Gross, K.E. \& Sanderson, S.S.: Radiology 77, 573, 1961.

13) Hinman, F. \& Hutch, J.A.: J. Urol. 87, 230. 1962.

14) Hodson, C.J.: Radiology 88, 857, 1967.

15) Hutch, J.A.: J. Urol. 68, 457, 1952.

16) Hutch, J.A., Smith, D.R. \& Osborne, K.: J. Urol. 100, 285, 1968.

17) Hutch, J.A. \& Smith, D.R.: Urol. Int. 24, 460, 1969.

18) Küss, R., Chatelain, C. \& Thibault, P.: $15^{\mathrm{e}}$ Congrès de la Société Internationale d'Urologie (Tokyo) 1970, Tome II, p. 197, G. et R. Joly (Paris).

19) Lipsky, H. \& Chisholm, G.D.: Brit. J. Urol.
43, 277, 1971.

20) Lyon, R.G., Marshall, S. \& Tanagho, E.A.: J. Urol. 102, 504, 1969.

21) O'Donnell, B., Maloney, M.A. \& Lynch, V.: Brit. J. Urol. 41, 6, 1969.

22) Paquin, Jr., A.J., Marshall, U.F. \& McGovern, J.H.: J. Urol. 83, 634, 1960.

23) Politano, V.A.: J. Urol. 90, 696, 1963.

24) Sargent, J.W.: J. Urol. 91, 650, 1964.

25) Shannon, F.T.: In "Renal Infection and Rena! Scarring" edited by Kincaid-Smith \& Fairley, p. 241, Mercedes Publishing Services (Melbourne) 1970.

26) Shopfner, C.E.: Radiology 95, 637, 1970.

27) Stecker, Jr., J.F., Rose, J.G. \& Gillenwater, J.Y.: J. Urol. 110, 341, 1973.

28) Stephens, F.D. \& Lenaghan, D.: J. Urol. 87, 669, 1962.

29) Tanagho, E.A. \& Pugh, R.C.B.: Brit. J. Urol. 35, 151, 1963.

30) Tanagho, E.A. \& Hutch, J.A.: J. Urol. 93, 158, 1965.

31) Weiss, S. \& Parker, F.: Medicine 18, 221, 1939.

32) Williams, D.I. \& Eckstein, H.B.: Brit. J. Urol. 37, 13, 1965.

33) Williams, D.I.: Urol. Int. 26, 350, 1971.

(1974年 3 月11日受付) 